\title{
Redescription of Nanacalathis atlantica Zezina, 1991 (Brachiopoda: Chlidonophoridae) from the North Atlantic
}

\author{
Maria Aleksandra Bitner ${ }^{1}$ - Tina N. Molodtsova ${ }^{2}$ \\ Received: 8 September 2016 / Revised: 9 February 2017 / Accepted: 21 February 2017 / Published online: 6 March 2017 \\ (C) The Author(s) 2017. This article is published with open access at Springerlink.com
}

\begin{abstract}
The chlidonophorid brachiopod species Nanacalathis atlantica Zezina, 1991 has been identified in material from the north tropical Mid-Atlantic Ridge, between $16^{\circ} 56^{\prime}-16^{\circ} 51^{\prime} \mathrm{N}$ at the depth range $3227-3474 \mathrm{~m}$, collected during the 37th cruise of the RV Professor Logachev in February-March 2015. This rich new material allows us to redescribe and properly illustrate this poorly known, deepwater species that was established on the basis of one empty shell. The spiculation within the lophophore and tentacles is heavy with the pattern characteristic for the subfamily Eucalathinae.
\end{abstract}

Keywords Brachiopoda Cancellothyridoidea .

Chlidonophoridae $\cdot$ Nanacalathis $\cdot$ Mid-Atlantic Ridge

\section{Introduction}

The genus Nanacalathis, with the type species Nanacalathis minuta Zezina, 1981, was erected by Zezina (1981) for Recent cancellothyridid brachiopods from the Indian Ocean resembling Eucalathis Fischer and Oehlert, 1890, but having conjunct deltidial plates. Ten years later, Zezina (1991)

Communicated by P. Martinez Arbizu

Maria Aleksandra Bitner

bitner@twarda.pan.pl

Tina N. Molodtsova

tina@ocean.ru

1 Institute of Paleobiology, Polish Academy of Sciences, ul. Twarda 51/55, 00-818 Warszawa, Poland

2 P.P. Shirshov Institute of Oceanology, Russian Academy of Sciences, 36 Nakhimovsky prospect, Moscow 117997, Russia described another species of Nanacalathis, N. atlantica Zezina, 1991 from the Atlantis Fracture Zone of the MidAtlantic Ridge (MAR) at $26^{\circ} \mathrm{N}$ at the depth of $3650 \mathrm{~m}$. This species was established on the basis of one empty shell and only drawings of the holotype were presented. However, the specimen described by Cooper (1973) as Eucalathis? sp. was included in N. atlantica by Zezina (1991). Later, a living specimen of $N$. atlantica was found in a sample collected on the eastern slope of the Great Meteor Seamount at a depth of 3340-3440 m (Zezina 2006, 2010; Fig. 1).

Recently, in the course of ecological assessment of the Russian claim area at the MAR (Molodtsova et al. 2017 in press), numerous specimens of $N$. atlantica have been collected and the aim of this paper is to redescribe and properly illustrate this poorly known, deep-water species.

\section{Material and methods}

Brachiopods were collected in February-March 2015 during the 37th Russian cruise of the RV Professor Logachev to the Mid-Atlantic Ridge. The sampled area was located in the axial zone of the MAR between $17^{\circ} 14^{\prime} \mathrm{N}$ and $16^{\circ} 40^{\prime} \mathrm{N}$ (Molodtsova et al. 2017, in press) (see Fig. 1). The examined specimens (296 articulated specimens plus 67 separate valves) were found at two stations, 37L130dt and 37L158dt, both on the western slope of the rift valley. Apart from Nanacalathis atlantica, one specimen of Leptothyrella incerta (Davidson, 1880) was found at station 37L130dt.

For electron-microscope examination, selected specimens were coated with platinum and examined using a Philips XL20 SEM at the Institute of Paleobiology, Warszawa. Photographs were taken with a Leica DFC-490 microscope digital camera attached to a Leica M165 C stereomicroscope and stacked image was created using CombineZP software 
Fig. 1 Map of the North Atlantic Ocean showing locations of Nanacalathis atlantica Zezina, 1991, diamond type locality, star this publication, circles other localities; data after Cooper (1973), Zezina (1991, 2006, 2010, 2014), and this paper

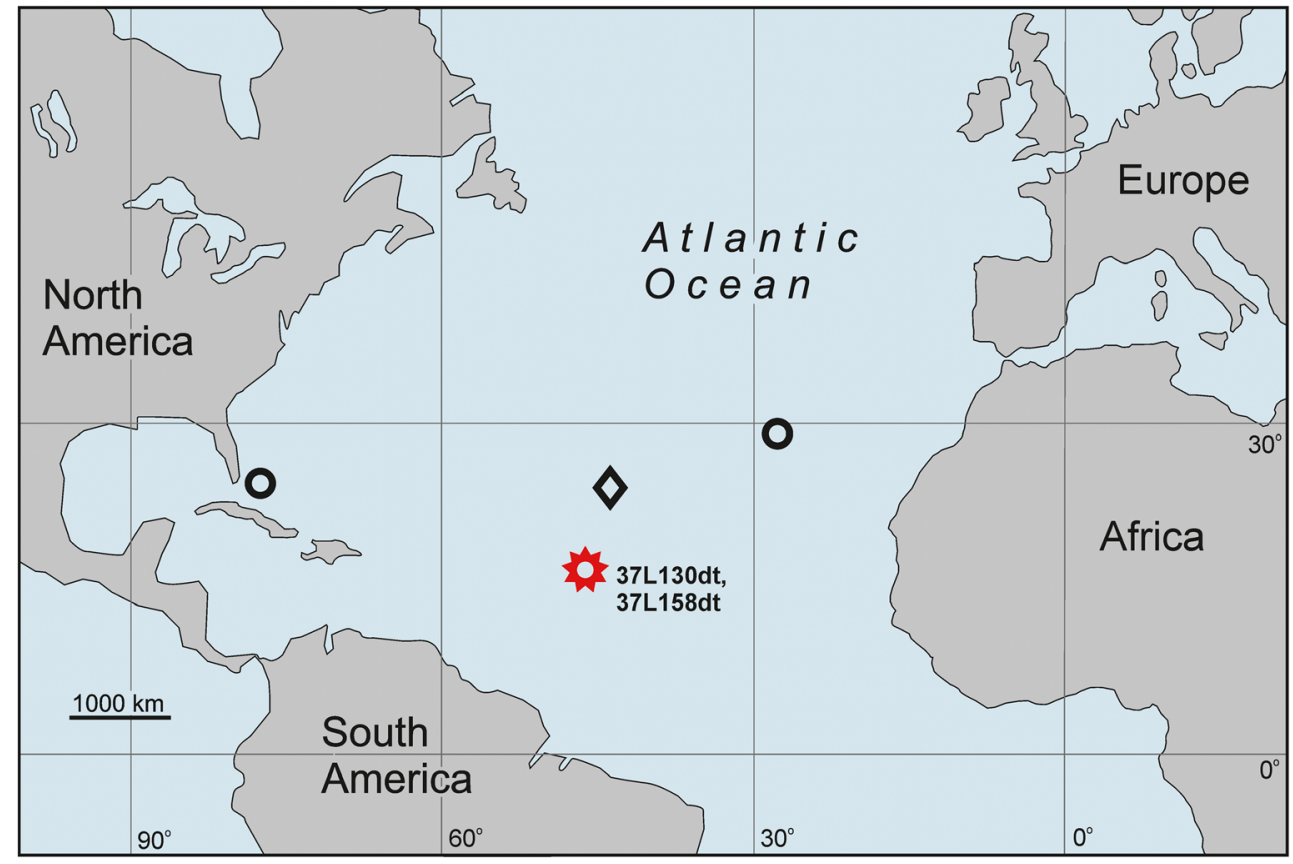

(Hadley 2010). The majority of the material described here is housed at the P.P. Shirshov Institute of Oceanology, Russian Academy of Sciences, Moscow (collection IORAS without number), about 50 specimens are kept at the Institute of Paleobiology, Polish Academy of Sciences, Warszawa under the collection number ZPAL Bp.79.

\section{Results}

\section{Systematics}

Superfamily Cancellothyridoidea Thomson, 1926

Family Chlidonophoridae Muir-Wood, 1959
Subfamily Eucalathinae Muir-Wood, 1965

Genus Nanacalathis Zezina, 1981

Type species Nanacalathis minuta Zezina, 1981, by original designation of Zezina (1981: 162).

Distribution of the genus Indian Ocean (289 m), North Atlantic (3227- $3731 \mathrm{~m}$ ).

\section{Nanacalathis atlantica Zezina, 1991}

Figs. 2-6

Eucalathis? sp. - Cooper 1973: 14-15, pl. 4, figs 14-17.

Nanacalathis atlantica Zezina 1991: 152-153, text-fig. 1.

Nanacalathis atlantica - Zezina 2000: 30; Zezina 2006: 70; Zezina 2010: 1187; Zezina 2014: 86.

Material examined RV Professor Logachev: stn $37 \mathrm{~L} 130 \mathrm{dt}, 16^{\circ} 56^{\prime} \mathrm{N}, 46^{\circ} 32^{\prime} \mathrm{W}$, depth $3412-3474 \mathrm{~m}, 284$
Fig. 2 Intraspecific variation in Nanacalathis atlantica (Zezina, 1991). Scatter diagram plotting length/width. $\mathrm{N}$ number of specimens

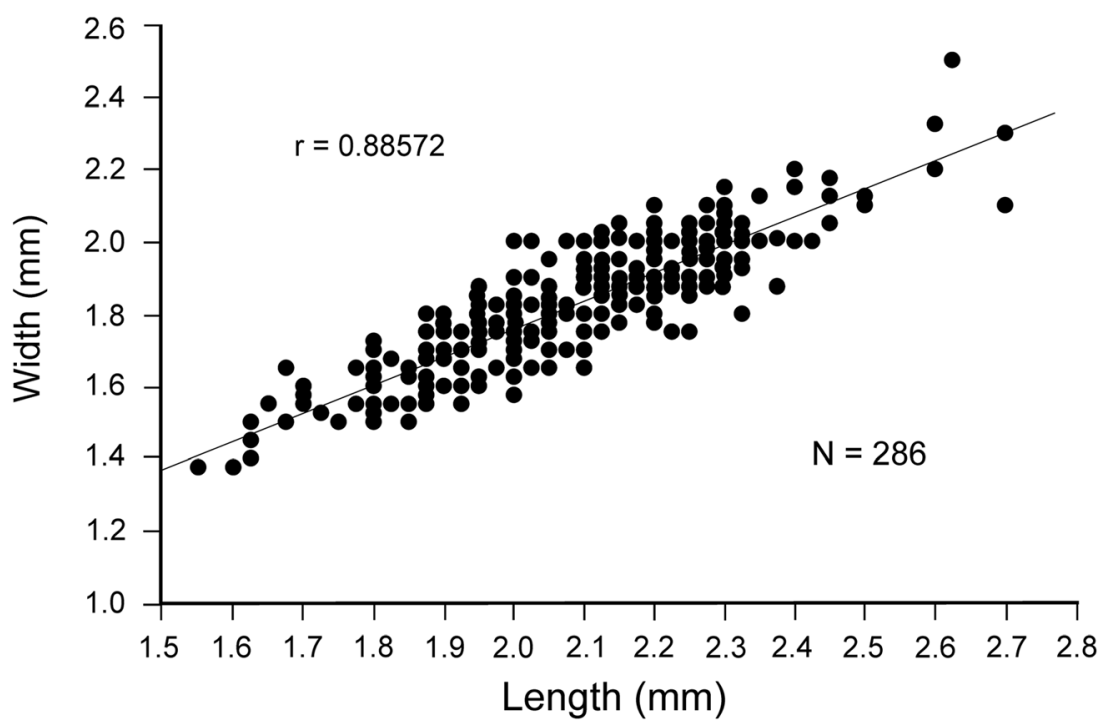




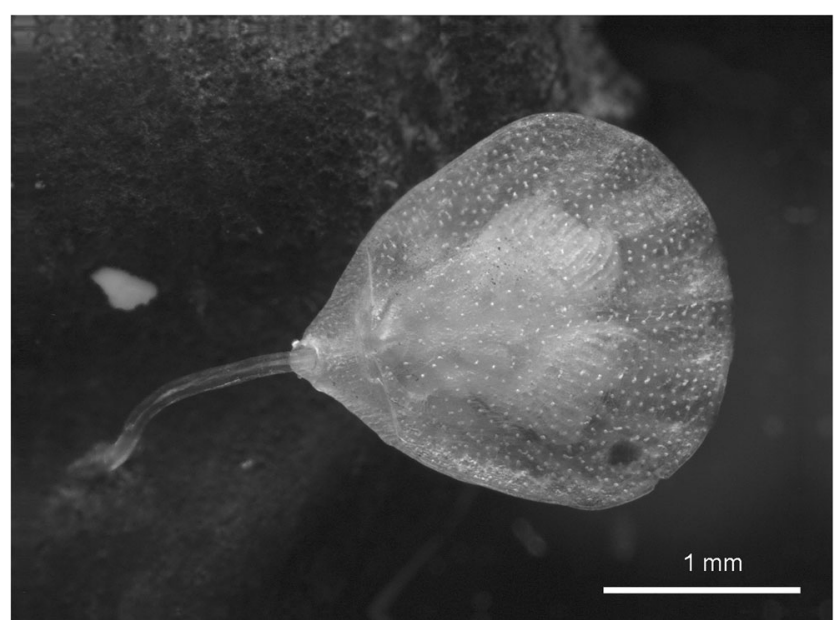

Fig. 3 Nanacalathis atlantica Zezina, 1991, 37th cruise of the RV Professor Logachev, stn 37L158, depth 3227-3283 m, complete living specimen (IORAS collection) attached by a pedicle to a fragment of pteropod shell, dorsal view

complete specimens, 24 ventral and 43 dorsal valves; stn $37 \mathrm{~L} 158 \mathrm{dt}, 16^{\circ} 51^{\prime} \mathrm{N}, 46^{\circ} 33^{\prime} \mathrm{W}$, depth $3227-3283 \mathrm{~m}, 12$ complete specimens, one with a pedicle.

Measurements Max. length $2.7 \mathrm{~mm}$, width $2.3 \mathrm{~mm}$, thickness $1.0 \mathrm{~mm}$. Length from 1.5 to $2.7 \mathrm{~mm}$ (mean $=2.09 \mathrm{~mm}, \mathrm{n}=286$ ); width from 1.3 to $2.5 \mathrm{~mm}$ (mean $=1.83 \mathrm{~mm}, \mathrm{n}=286$ ); thickness from 0.5 to $1.0 \mathrm{~mm}$ (mean $=0.71 \mathrm{~mm}, \mathrm{n}=102$ ) (see also Fig. 2).
Depth range for the species $3227-3731 \mathrm{~m}$.

Ecological note The only intact specimen collected was attached to a pteropod shell with a prominent pedicle (Fig. 3). The long pedicle in $N$. atlantica was also reported by Cooper (1973) and Zezina (2006), but has never been illustrated.

Distribution Central Western Atlantic (off the Bahamas), Great Meteor Seamount, north tropical Mid-Atlantic Ridge, upper abyssal zone (see Fig. 1).

\section{Description}

Shell small (max. observed length $2.7 \mathrm{~mm}$ ), thin, elongate triangular in outline with rounded anterior margin, ventribiconvex (Fig. 4). Shell surface covered with 6-10 broad, smooth ribs, triangular in profile; growth lines numerous. Lateral commissure straight, anterior commissure rectimarginate. Hinge line narrow, straight to incipiently curved. Beak long, suberect with narrow, flat interarea, and distinct beak ridges. Foramen rounded, mesothyrid; deltidial plates conjunct forming a thick, convex symphytium with distinct growth lines. Pedicle long and thin (Fig. 3).

Ventral valve interior with a well-developed pedicle collar (Fig. 5a-e) . Teeth wide, hooked. Dorsal valve interior with prominent inner socket ridges projecting
Fig. 4 Nanacalathis atlantica Zezina, 1991, 37th cruise of the RV Professor Logachev, all specimens stn 37L130 (depth 3412-3474 $\mathrm{m}$ ), except $\mathbf{h}$, which is 37L158 (depth 3227-3283 m). a, b dorsal views of young complete specimens, ZPAL Bp.79/1-2. c ventral view of complete specimen, ZPAL Bp.79/3. d lateral view of complete specimen, ZPAL Bp.79/4. e dorsal view of complete specimen, ZPAL Bp.79/ 5. $\mathbf{f}-\mathbf{k}$ dorsal views of complete specimens $(\mathbf{f}, \mathbf{h}, \mathbf{j})$ and enlargement $(\mathbf{g}, \mathbf{i}, \mathbf{k})$ of the umbonal part to show details of the beak, ZPAL Bp.79/6-8. I dorsal view of complete specimen, ZPAL Bp.79/9. All SEM

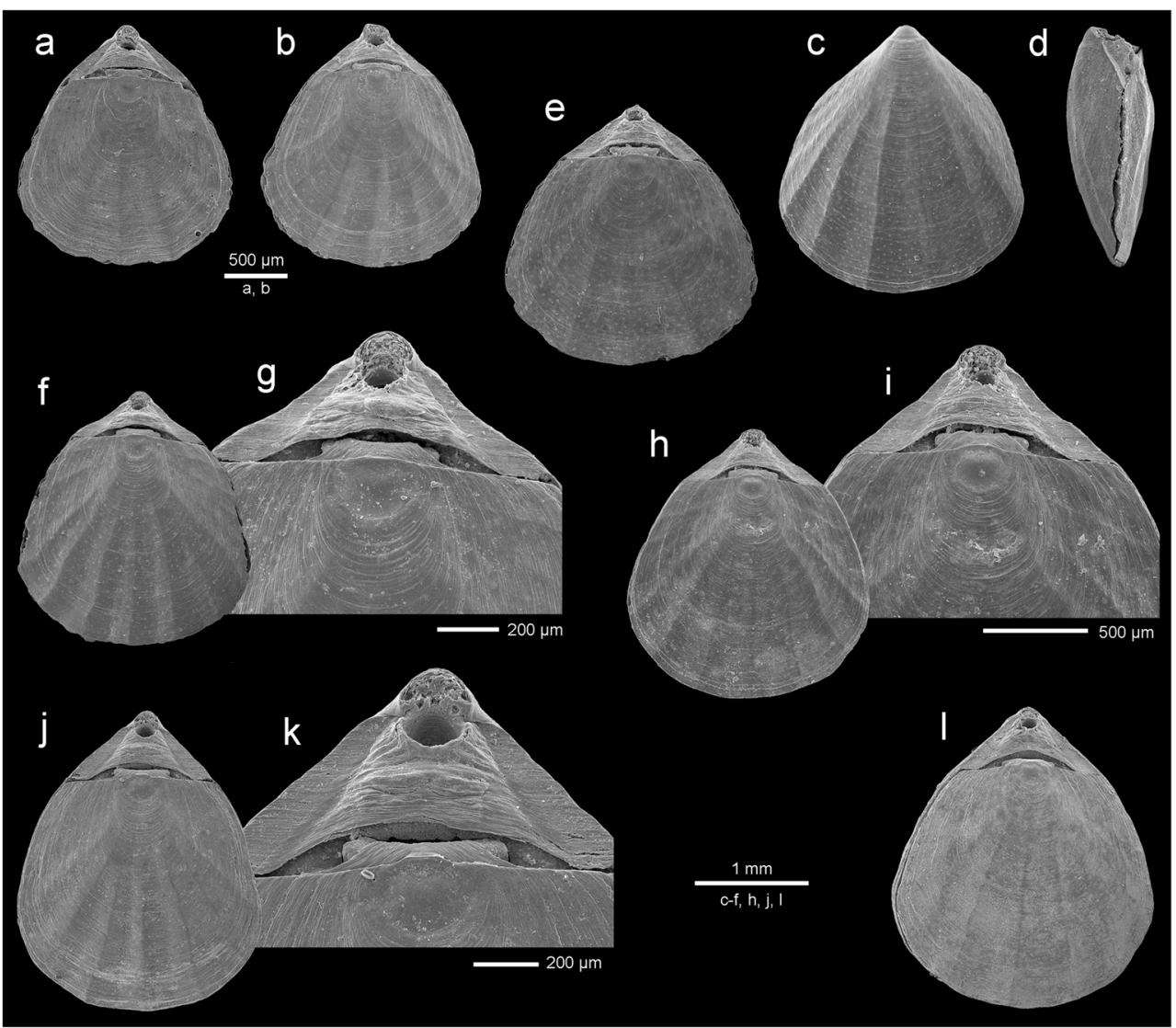


Fig. 5 Nanacalathis atlantica Zezina 1991, 37th cruise of the RV Professor Logachev, all specimens stn 37L130, depth 3412-3474 m. a-e inner views of ventral valves and enlargement of posterior part $(\mathbf{b}, \mathbf{d})$, and tilted view (e) to show thick

symphytium, ZPAL Bp.79/10-11. f-j inner and oblique views of dorsal valve, and enlargement (j) of crura, ZPAL Bp.79/12. All SEM
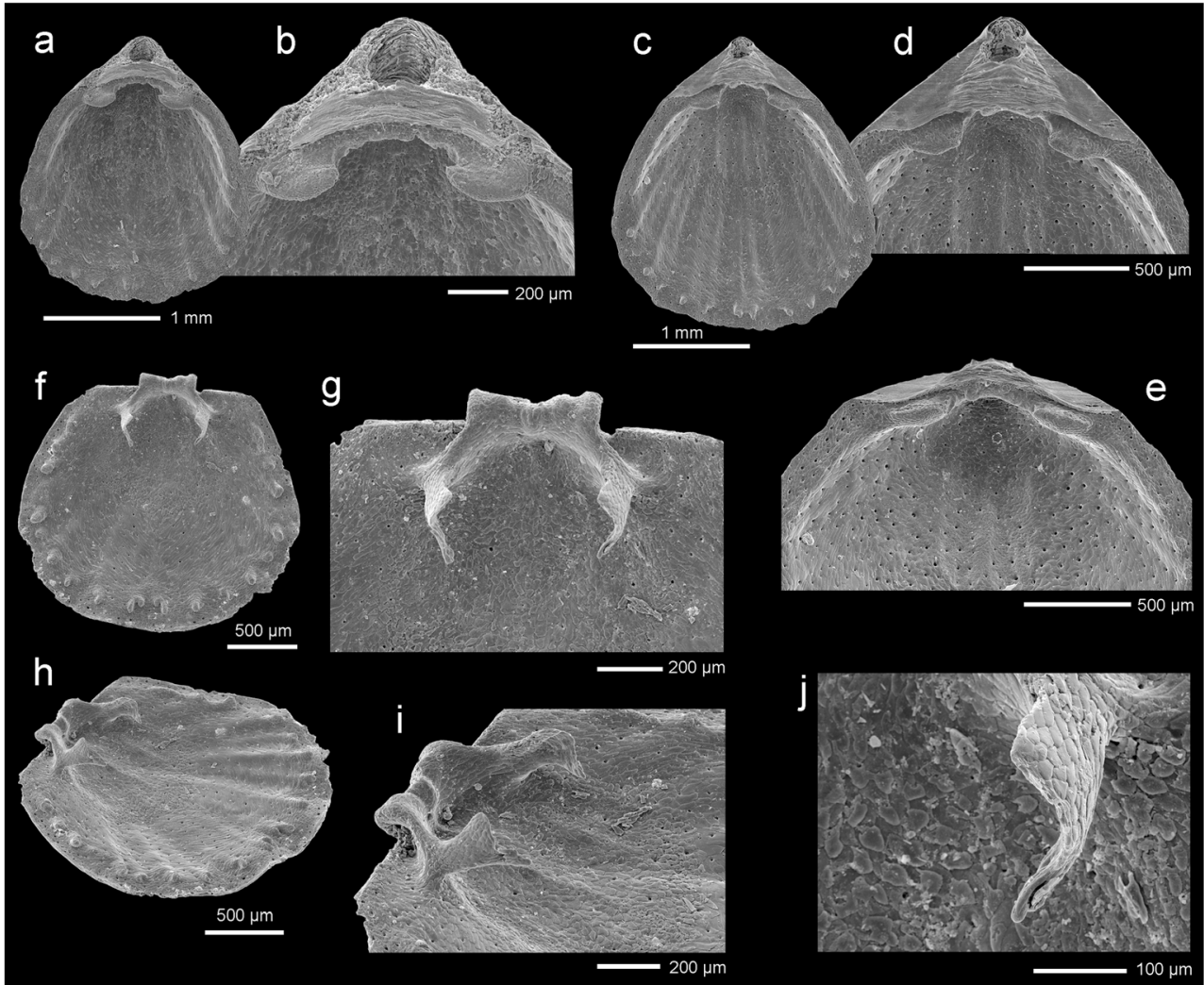

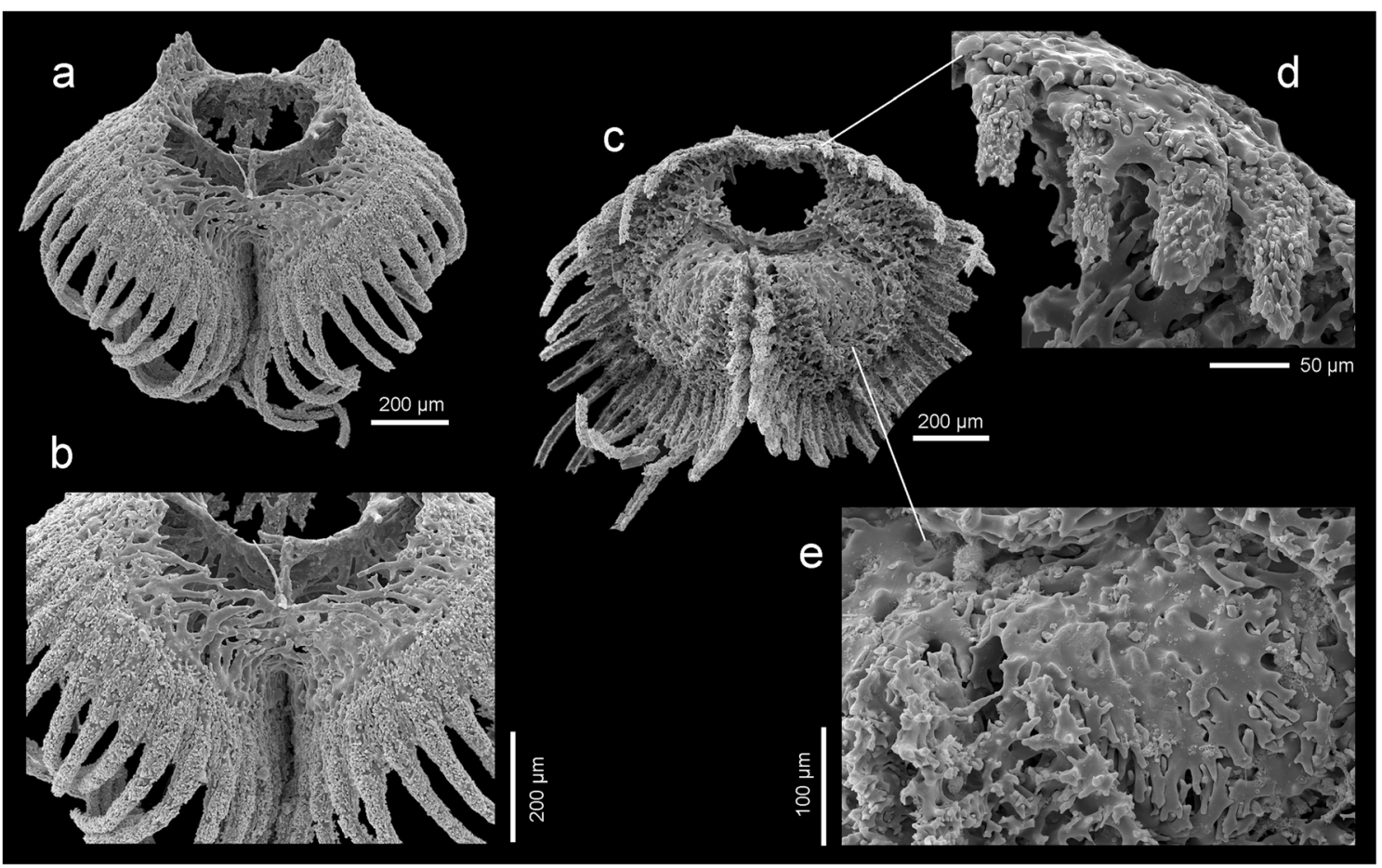

Fig. 6 Nanacalathis atlantica Zezina, 1991, 37th cruise of the RV Professor Logachev. a, b ventral view of lophophoral endoskeleton showing two extentions, speculated tentacles and multibranched spicules in the centre (b), stn 37L158, depth 3227-3283 m. c-e dorsal view of lophophoral endoskeleton, and enlargement of tilted posterior part (d) and heavy inside spiculation (e) to show details of flattened spicules, stn 37L130, depth 3412-3474 m. All SEM 
beyond hinge line (Fig. 5f-i). Sockets large. Cardinal process small, united with the socket ridges. Crura short, but wide with flattened endings, parallel to slightly convergent (Fig. 5j). No loop. Inner surface with low radial ridges terminating anteriorly with marginal tubercles.

The spiculation within the lophophore and tentacles is strong. Posteriorly, two extensions project towards crura (Fig. 6a). The lophophoral endoskeleton is massive and dense, with differentiated spicules. On the ventral side the spicules inside the loop are multibranched (Fig. 6b). Dorsally, the spicules in the centre and in the posterior part are thick, plateshaped, finger-branched, often articulated (Fig. 6c-e). The spicules of tentacles are small, half-cylinder shaped, forming a groove on dorsal side (Fig. 6c, d).

\section{Remarks}

So far Nanacalathis atlantica is known from only three specimens. This newly collected, rich material allows us to redescribe and properly illustrate this species and its variability.

Nanacalathis atlantica differs from the Indian Ocean Nanacalathis minuta by having a smaller number of ribs (610 vs. 12-14) (Zezina 1981). Additionally, N. minuta is much smaller, reaching only $1.8 \mathrm{~mm}$ long.

Conjunct deltidial plates are also observed in the newly erected eucalathine, Rectocalathis schemmgregoryi Seidel and Lüter, 2014; however, this brachiopod has an epithyrid foramen with the pedicle opening lying in a subumbonal position on the ventral side, differing clearly from the species described here (Seidel and Lüter 2014). The shell surface in $R$. schemmgregoryi is nearly smooth, whereas in both Nanacalathis species ribbed ornamentation is present. Additionally, marginal tubercles are present in $N$. altantica but not in $R$. schemmgregoryi.

The pattern of spiculation in Nanacalathis, investigated here for the first time, is characteristic for the subfamily Eucalathinae, being most similar to that in Rectocalathis (see Seidel and Lüter 2014). The main function of spiculation seems to be the mechanical support for the soft tissue of the lophophore. However, heavy spiculation may also play an anti-predator role (Seidel and Lüter 2014).
Acknowledgements The cruise was organised by the Polar Marine Geosurvey Expedition and financed through the Federal Subsoil Resources Management Agency of the Ministry of Natural Resources of the Russian Federation. T. Molodtsova was supported in part by the RSF grant 14-50-00095 (sorting of material). We are thankful to Bernard L. Cohen (University of Glasgow, Glasgow, UK) for critically reading the earlier version of the manuscript, useful comments, and improving English. Comments by two anonymous reviewers are gratefully acknowledged.

Open Access This article is distributed under the terms of the Creative Commons Attribution 4.0 International License (http:// creativecommons.org/licenses/by/4.0/), which permits unrestricted use, distribution, and reproduction in any medium, provided you give appropriate credit to the original author(s) and the source, provide a link to the Creative Commons license, and indicate if changes were made.

\section{References}

Cooper GA (1973) Vema's Brachiopoda (Recent). Smiths Contrib Paleobiol 17:1-51

Hadley A (2010) Combine ZP Software, new version, [WWW document]. URL. http://www.hadleyweb.pwp.blueyonder.co.uk/ (accessed 08.10.14)

Molodtsova TN, Galkin SV, Kobylansky SG, Simakova UV, Vedenin AA, Dobretsova IG, Gebruk AV (2017) First data on benthic and fish communities from the Mid-Atlantic Ridge, 1640' - 1714'N. Deep-Sea Research II in press 10.1016/j.dsr2.2016.10.006

Seidel R, Lüter C (2014) Overcoming the fragility - X-ray computed micro-tomography elucidates brachiopod endoskeletons. Front Zool 11:65

Zezina ON (1981) New and rare cancellothyroid brachiopods. Trudy Inst Okeanol 115:155-164 [in Russian with English summary]

Zezina ON (1991) A new species of cancellothyroid brachiopods from the "Atlantis" Fault Zone of the Mid-Atlantic Ridge. Zool Zh 70: 152-153 [in Russian with English summary]

Zezina ON (2000) Russian collections of deep-sea brachiopods in the Atlantic Ocean. Eds AP Kuznetsov, ON Zezina, Benthos of the Russian Seas and the Northern Atlantic. Moscow: VNIRO Publishing House p. 26-36 [in Russian with English summary]

Zezina ON (2006) Deep-sea brachiopods in Russian collections from the Atlantic Ocean. Eds AN Mironov, AV Gebruk, AJ Southward, Biogeography of the North Atlantic seamounts. Moscow: KMK Scientific Press Ltd. P. 67-75

Zezina ON (2010) Check-list of Holocene brachiopods annotated with geographical ranges of species. Paleont J 44:1176-1199

Zezina ON (2014) Deep-sea fauna of European seas: an annotated species check-list of benthic invertebrates living deeper than $2000 \mathrm{~m}$ in the seas bordering Europe. Brachiopoda. Invert Zool 11:83-88 